\title{
Proceeding
}

Supplementary Issue: Rio 2016 Olympic Games Fourth Anniversary Special Edition. Olympic Studies Forum, 21-24 October 2020. Olympic Studies Research Group, Pontifical Catholic University of Rio Grande do Sul (GPEO PUCRS), Brazil

\section{eMuseum of sports: Digital and televised media impact stemming from the virtual galleries and exhibitions}

\author{
BIANCA GAMA PENA ${ }^{1,2}$, SILVIO DE CASTRO TELLES 3,4, RODRIGO VILELA ELIAS ${ }^{4}$, RITA MACHADO², \\ LAMARTINE PEREIRA DACOSTA ${ }^{4}$, MARINILZA BRUNO DE CARVALHO ${ }^{1}$, MARCIO TURINI ${ }^{5}$ \\ ${ }^{1}$ Innovation Department, State University of Rio de Janeiro (UERJ), Rio de Janeiro, Brazil \\ ${ }^{2}$ National Institute of Industrial Property, Rio de Janeiro, Brazil \\ ${ }^{3}$ School of Physical Education and Sport, Federal University of Rio de Janeiro (UFRJ), Rio de Janeiro, Brazil \\ ${ }^{4}$ Institute of Physical Education and Sports, State University of Rio de Janeiro (UERJ), Rio de Janeiro, Brazil \\ ${ }^{5}$ Physical Education and Sports Center/UNIABEU, Rio de Janeiro, Brazil
}

\begin{abstract}
Museums are important instruments for preserving a group's cultural memory and are responsible for its material or immaterial heritage. Furthermore, they participate in the tourism economy and in productive projects that contribute to the quality of life in the communities and regions in which they are located. Thus, in a period marked by the Coronavirus pandemic, with lockdowns going on in various parts of the world, online platforms for cultural consumption have been highlighted as a manner of guaranteeing entertainment and cultural access to the whole population. Thus, the present study aims to present the media impact results for the eMuseum of Sports in Brazilian digital and televised media. To fulfil this goal, the documental analysis technique was used to conduct a survey of the Sports eMuseum's impact through digital data. The internet data was obtained from the social networks Facebook and Instagram and the eMuseum's website, where all of its exhibits are concentrated. These digital communication media possess data analysis metrics that show how a certain post was followed by the public that uses these networks. Between April and October of 2020, the eMuseum of Sports launched 83D exhibits and 83D Galleries. On observing the gallery and exhibit contents in numbers, there are 184 collections (images or videos) in the exhibits and 560 in the galleries. At the end of this period, the total reach on the eMuseum's social networks arrived at the expressive number of almost 4 million and 300 thousand people impacted by the content that was created and organized by the eMuseum. The conclusion is that the eMuseum of Sports had a significant media coverage and allowed content to be accessed, strengthening the democratization of various sports content at a moment when other forms of in-person visitation would not be possible.
\end{abstract}

Keywords: eMuseum; Sports; Technology.

Cite this article as:

Pena, B.G., Telles, S.C., Elias, R.V., Machado, R., DaCosta, L.P., de Carvalho, M.B., \& Turini, M. (2021). eMuseum of sports: Digital and televised media impact stemming from the virtual galleries and exhibitions. Journal of Human Sport and Exercise, 16(1proc), S84-S91. doi:https://doi.org/10.14198/jhse.2021.16.Proc1.08

Corresponding author. Innovation Department, State University of Rio de Janeiro (UERJ), Rio de Janeiro, Brazil. https://orcid.org/0000-0001-7765-2486

E-mail: biancagamapena@gmail.com

Supplementary Issue: Rio 2016 Olympic Games Fourth Anniversary Special Edition. Olympic Studies Forum, 21-24 October 2020. Olympic Studies Research Group, Pontifical Catholic University of Rio Grande do Sul (GPEO PUCRS), Brazil.

JOURNAL OF HUMAN SPORT \& EXERCISE ISSN 1988-5202

(C) Faculty of Education. University of Alicante

doi:10.14198/jhse.2021.16.Proc1.08 


\section{INTRODUCTION}

Museums are important instruments for preserving a group's cultural memory and are responsible for its material or immaterial heritage. Furthermore, they participate in the tourism economy and in productive projects that contribute to the quality of life in the communities and regions in which they are located.

At the end of the year 2019, a new virus appeared in the city of Wuhan, in China. The virus, (SARS-CoV-2), which is a part of the coronavirus family, can cause damage in humans and animals. In human beings, it can lead to respiratory infections that vary from colds to acute syndromes, causing the illness known as COVID19 (Ministério da Saúde, 2020). Thus, in a period marked by the coronavirus pandemic with lockdowns occurring in various parts of the world, online platforms for culture consumption have been thrust into the spotlight as a way of guaranteeing entertainment and cultural access to the whole population. At a moment when museum visits in search of leisure, entertainment and culture have been condemned by the main governments in an attempt to mitigate the spread of the disease, virtual platforms are not only desirable but also one of the only forms of developing and maintaining this type of activity.

In the new technological society, to integrate virtual with reality is one of the new challenging aspects presented to professionals from various fields of work. Incorporating virtual experiences to real practices may not only lead to better results in the diffusion and reception of information but also in the management and operationalization of financial expenses. To Lévy (2001, p.51), the current economy is an economy of deterritorialization or virtualization that can contribute towards simplifying pathways, reducing complexities and expenses.

In this context, Digital Museology presents itself as a new field for technological development with the intent to strengthen the access to history and memory and their sharing through innovation. To evaluate this perspective, this study will evaluate the project known as eMuseum of Sports.

The eMuseum of Sports was created after the Rio de Janeiro 2016 Olympic Games with the challenging goal of becoming a virtual hub for engaging athletes, sportive entities, museums and fans in the act of preserving sportive memories through combinations of digital technologies.

The project occurs through a virtual platform that is accessible to the public and gathers collections from athletes, collectors, sports fans and sportive entities, making it an Olympic sports ecosystem and a memory centre for sociocultural purposes (Pena, 2019). An ecosystem is herein comprehended as an environment comprised of various actors that interact among themselves (Etzkowitz, 2006). In this specific case, the established ecosystem contains memory, productivity and knowledge innovation.

In 2020, at the end of the construction and facilitation period for the project, the eMuseum began to launch its virtual exhibits. Between April and October, which is the period analysed by this study, 16 exhibits were launched, divided between 3D Exhibits and 3D Galleries, that will be further explained in the Materials and Methods section.

With this in mind, a question appeared about the size of the project's initial media impact in the digital environment with the social networks Facebook and Instagram and the eMuseum's official website as well as its televised impact due to a project that used television as a promotion tool. Thus, the present study aims to present the media impact results for the eMuseum of Sports in Brazilian digital and televised media. 


\section{METHODOLOGICAL PROCEDURES}

To achieve the goal proposed by this study, the documental analysis technique was chosen to conduct a survey of the Sports eMuseum's media impact through digital data. Documental research is different from other types as it uses information that is created and available electronically and not directly obtained from people (Gil, 2010).

The concept of document surpasses the idea of written and/or printed texts. Documents as research sources can be written or not, such as movies, videos, photographs or posters. These documents are used as information sources, signs and explanations whose content elucidates certain questions and serves as proof for others, depending on the researcher's interests (Figueiredo, 2007).

With the evolution of digital media, the documental sources that were normally characterized as written, as is the case for public archives and official documents, have currently expanded to include TV, CDs, DVDs, digitized files in computer centrals and data obtained from the world wide web, also known as the internet (Gil, 2010). However, this data is not limited to what is shared by regular news sources, but actually expands according to this network's reach and the behaviour exhibited by the people who are connected to it on a daily basis.

In this article, the internet and TV were specifically chosen to describe the Sports eMuseum's reach. The internet data was obtained through the social networks Facebook and Instagram and the eMuseum website, where all of the exhibits are concentrated. These digital communication media possess data analysis metrics which show how a certain post impacted the public that uses them. Thus, the following numbers regarding the publications were computed.

1. Reach - number of individual accesses for the posts.

2. Impressions - number of times the posts were accessed.

3. Stories impressions - number of times the stories were viewed.

4. Engagement - number of times users interacted with the posts through comments, likes and/or saving the posts as favourites.

5. Comments - Number of comments on the posts.

6. Likes - Number of likes the posts received.

7. Visualizations - number of users who accessed the eMuseum website.

8. Sessions - number of visits the eMuseum's website received.

These numbers are provided by the social networks themselves and, in the website's case, through internet analysis tools. Said numbers can only be measured and not manipulated. The data is made available monthly and, whenever necessary, the administrator/proprietor for the social network accounts and website can access it, with the possibility of determining only the period of time over which the metrics are computed. For this article, the chosen time period goes from April 19th, date of the first exhibit launch to October $23^{\text {rd }}$, when the Pelé 80 years exhibit was launched.

Despite the competition from the internet, TV is a mass communication medium that is highly present in daily life and is tenacious, with a high capability for adaptation. Currently, this medium has shown itself to be connected with information technology advancements, allying its standard programming with the internet's interactivity which allows programs and news reports to be watched wherever and whenever users want, 
through smartphones. Thus, according to McLuhan (2007, p. 376), the image of TV as an extension of the sense of touch, an experience, now fits in the palm of one's hand.

With this in mind, the TV was another manner of connection between the museum and the public through news reports that promoted the main exhibits, such as the 70 years of Maracanã and Pelé's 80th birthday. The news programs RJ-TV first and second editions from Rede Globo, Jornal das 10 from Globo News highlighted the eMuseum in their programs.

The program penetration numbers come from lbope and point to average audience numbers, which determine the TV programs' reach and, consequently, that of its content when the eMuseum related content was on-air. These numbers were provided by the TV network.

\section{DATA PRESENTATION AND DISCUSSION}

Between April and October 2020, the eMuseum of Sports launched 8 3D Exhibits and 8 3D Galleries. The difference between Exhibits and galleries mainly resides in the amount of material they hold, with the exhibits being smaller than the galleries. The exhibits contain up to 43 screens with images or videos in up to two three-dimensional environments. The galleries, despite being shown in a single three-dimensional environment, can hold up to 77 images or videos. By turning the content in the exhibits and galleries into numbers, we have 184 collections (images or videos) in the exhibits and 560 in the galleries.

The following Table 1 contains all of the exhibits and galleries launched by the eMuseum. They are organized in chronological order and are also a part of the media numbers that will be presented later on in the article.

Table 1.Launch schedule for exhibits and galleries.

\begin{tabular}{|c|c|}
\hline Launch schedule for Exhibits and Galleries & \\
\hline Exhibit - Science x Myths: the 1970 World Cup & April 19th, 2020 \\
\hline Exhibit - Olympic and Paralympic Collaboration - Part I & May $8^{\text {th }}, 2020$ \\
\hline Exhibit - Olympic and Paralympic Collaboration - Part II & May $22^{\text {nd }}, 2020$ \\
\hline $\begin{array}{l}\text { Exhibit - The Post-Pandemic Reinvention of Sport and the Olympic Games - Part } \\
\text { | }\end{array}$ & June $5^{\text {th }}, 2020$ \\
\hline Gallery - Enel & June $15^{\text {th }}, 2020$ \\
\hline Gallery - Brazilian Basketball Confederation & June $15^{\text {th }}, 2020$ \\
\hline Gallery - Brazilian Canoeing Confederation & June $15^{\text {th }}, 2020$ \\
\hline Gallery - Brazilian Table Tennis Confederation & June $15^{\text {th }}, 2020$ \\
\hline Exhibit - Maracanã: 70 Years & June $16^{\text {th }}, 2020$ \\
\hline $\begin{array}{l}\text { Exhibit - The Post-Pandemic Reinvention of Sport and the Olympic Games - Part } \\
\text { II }\end{array}$ & June $19^{\text {th }}, 2020$ \\
\hline Gallery - Brazilian Committee of Master Sports & August $26^{\text {th }}, 2020$ \\
\hline Gallery - Military Sport & August 26th, 2020 \\
\hline Gallery - International Museum of Sport & August $26^{\text {th }}, 2020$ \\
\hline Gallery - Brazilian Paralympic Committee & September 21 st, 2020 \\
\hline Exhibit - Physical Education Professionals: Champions of Daily Life & September 30th, 2020 \\
\hline Exhibit - Pelé 80 Years & October $23^{\text {rd }}, 2020$ \\
\hline
\end{tabular}


The eMuseum of Sports promoted these exhibits and galleries through its social networks and its website, which concentrates all of this work. In order to do so, launch videos and various types of social media posts were created before and after the Exhibit and Gallery launches with some images of what users would find in their content. Also, sports personalities such as Oscar, Zico, Roberto Dinamite and Pelé made exclusive videos with the intent to promote the posts. At the end of seven months, the total numbers are presented below at the Table 2 .

Table 2. Digital total numbers.

\begin{tabular}{|c|c|}
\hline \multicolumn{2}{|c|}{ Facebook } \\
\hline Reach & 2.580 .496 \\
\hline Followers & 1.044 \\
\hline Impressions & 2.629 .481 \\
\hline Engagement & 82.714 \\
\hline Comments & 1.504 \\
\hline Shares & 2.576 \\
\hline \multicolumn{2}{|c|}{ Instagram } \\
\hline Reach & 1.701 .384 \\
\hline Followers & 3.234 \\
\hline Impressions & 1.911 .771 \\
\hline Engagement & 3.493 \\
\hline Comments & 198 \\
\hline Stories Impressions & 9.033 \\
\hline \multicolumn{2}{|c|}{ Site } \\
\hline Views & 110.397 \\
\hline Sessions & 38.341 \\
\hline Users & 23.735 \\
\hline
\end{tabular}

Data source: eMuseum Facebook, Instagram and Google analytics.

At the end of this period, the total reach for the eMuseum's social networks shows the expressive result of almost 4 million and 300 thousand people impacted by the content that was created and organized by the eMuseum. The content creation was based on partnerships that were set up so the work could happen. In this sense, 88 partnerships were established with private individuals, federations, confederations and sportive committees that are a part of the sports field, thus revealing the eMuseum's interactive capability as an agent capable of gathering the national and international sports community around its objectives.

In order for this community interaction to be complete, the content was made accessible so that blind and deaf people are also able to experience the museum. Thus, six galleries were created for blind people and another six galleries for the deaf.

It is possible to state that among the other phenomena, media's growing development exerted and continues to exert devastating influence in modern societal ways of life. Bourdieu had already pointed out this trend on stating "The development of the press is an indication, among others, of an unprecedented expansion of the cultural goods market" (Bourdieu, 1997, p. 70). Within an expansion of cultural goods and also consumption goods, said goods influence and build lifestyles based upon trends and there is a firm belief that what is being experienced now, in this moment of compulsory seclusion, will become a social characteristic. Digital platforms are an example of this. Their coverage and ease of access, diffusion and marketing potential are tools that are here to stay. The hypothesis that is pointed out in this article is ratified by the significant space 
covered by the eMuseum, allowing thousands of people to expand their knowledge without leaving the computer.

The eMuseum's TV experience shows limitations that social media does not have; that is, content propagation access is restricted, and its publication depends on mutual interests pertaining to the subject matter in question. With this, among the exhibits that were divulged on TV, only the Maracanã 70 years exhibit had this privilege. It was broadcasted on the Rede Globo network on the RJTV news program, which goes on air in early afternoon in its first edition and in early evening in its second edition and on the 100 ' clock news on closed news channel Globo News, which demonstrates that soccer is one of the subjects that attracts the most interest from the general public, especially when the news has to do with a monument to soccer, a stadium that was a part of so many memorable moments in national and international soccer.

Furthermore, despite the irrefutable pathway that the internet and social networks are tracing as new mass communication media, the numbers shown below demonstrate that the TV is still the communication medium with the largest popular reach, presented at the Table 3.

Table 3. Television impact.

\begin{tabular}{ll}
\hline Television - Maracanã 70 years & \\
\hline RJTV 1st Edition (Afternoon) & 705 thousand households \\
RJTV 2nd Edition (Evening) & 1.363 .000 households \\
$100^{\prime}$ clock news - GloboNews & 73.730 households \\
\hline
\end{tabular}

Data source: Ibope - http://www.ibope.com.brl. Accessed on June 16th, 2020.

This power shows when seven months of digital reach are compared with short periods of news reports broadcasted in the aforementioned news programs, which reached almost two million and two hundred thousand people; that is, half of the social network reach but in a much shorter time period, which makes the numbers even more expressive, even without the user engagement possibilities of comments, likes, sharing and saving that the social networks possess. For the museum, despite this revealing a competition of sorts, it also promotes the museum and perpetuates its content.

According to Bourdieu, the work, the artist, the philosopher, the athlete and their representations among their peers only exist within a network of visible and invisible relationships that define each individual's position in relation to the others; that is, a social position in relation to an aesthetic position. For this author, it is essential to think of the relationships that may be visible in the forms of coexistence, sociability or relationships between individuals, or even those of more abstract and structural relationships that organize the field (Bourdieu, 1997). The field theory proposed by the author leads to the inference of intra and extra-field dynamics, that interact from their beginning to their maturity as a social movement and also permit the analysis of situations in other fields that may be understood in a similar manner due to the particularities involving the agents and their tensions. The pressures exerted between the fields lead to changes that dictate customs and many times modify the habitus of an entire group or social class. Thus, it is clear that the impact caused by the pandemic had a very strong influence in the development/acceleration of technologies that can allow society an escape from ostracism and that the TV and the internet had a major role in this process.

Television's power of penetration may be explained by its symbolic rapture as an advent of the consolidation of the consumer goods industry in Brazil since the "television, by simply existing, has done a great service to the Brazilian economy: it has joined the consumers, potential or not, into a market economy" (Ortiz, 2006, p. 
128). Proof of this is that according to the 2016 census, only $2.8 \%$ of the interviewed households in the country did not have a television set (Gandra, 2018).

However, despite this habit still being dominant, it is constantly losing space to social networks and to the internet for various reasons, among which interaction stands out. With this, the business model created around the TV with publicity is in check, a national trend that is merely a reflex of a worldwide trend ratified by the falling audience numbers (Becker, Gambaro and Filho, 2015). The TV's advantage still resides in the free open channels and in a habit that will probably change with the new generations and new cultural consumption habits.

\section{CONCLUSION}

History is being constructed in an overwhelming manner in the year 2020. The pandemic caused by COVID19 not only altered the population's health on a planetary scale but also altered the perception of time and its use in an optimized manner. Foucault (1995) sagely teaches us that not everything is bad, but everything is potentially dangerous, although that does not exactly mean that it is bad. However, if everything is dangerous, then we shall always have something to do. This sentence shows us that the growth of forms of human digital interaction is a path we believe to be inexorable. There is no turning back. This readaptation that humanity is being forced to fulfil will leave indelible marks that will be felt for many years. Not everything is bad in this transformation, but everything can be considered dangerous. The relationships between people show us our most human characteristics. The need to socialize and be together, the concept of gregariousness, have been decisive in keeping humanity alive. Caution is necessary in order to not lose the essence of contact between people and so that technological development does not ignore human beings' ontological needs.

Thus, the need for adaptation has accelerated technological development in various fields more than ever before. Medicine attempts to develop a vaccine in record time and in the digital environment, there is a search for ways to keep knowledge circulating. The eMuseum enters this search to strengthen culture and entertainment while respecting the social distancing rules. Even after the highly awaited end of the pandemic, the eMuseum can continue to facilitate access to content that is usually difficult to reach.

In 2020, there were 8 3D exhibits and 8 3D Galleries, which reached a total of more than 4 million people. Social media and television were decisive in obtaining this reach, rooted on the social phenomenon that sport represents. The Maracanã stadium, with the celebration of its 70 years of existence, with its history full of events that go from pop star shows to final matches of soccer World Cups was, alongside the 80 years of the King of Soccer, Edson Arantes do Nascimento, Pelé, the eMuseum's high points so far. Thus, we offer to the world an accessible source of knowledge and culture that can bring information and leisure to a growing number of people. Distance is no longer an unpassable barrier and human hedonism can be progressively increased by technological advancements and their developments.

\section{REFERENCES}

Becker, V., Gambaro, D., Souza Filho, G.L. (2015). O impacto das mídias digitais na televisão brasileira: queda da audiência e aumento do faturamento. Palabra Clave 18 (2), 341-373. https://doi.org/10.5294/pacla.2015.18.2.3

Bourdieu, P. (1997). Sobre a televisão. Rio de Janeiro: Jorge Zahar.

Etzkowitz, H. \& Zhou, C. (2006). Triple Helix twins: innovation and sustainability. Science and Public Policy. 33 (1), 77-83. https://doi.org/10.3152/147154306781779154 
Figueiredo, N.M.A. (2007). Método e metodologia na pesquisa científica. 2a ed. São Caetano do Sul, São Paulo, Yendis Editora.

Foucault, M. (1995). A arqueologia do saber. Rio de Janeiro: Forense Universitária.

Gandra, A. (2018). Pesquisa diz que, de 69 milhões de casas, só 2,8\% não têm TV no Brasil. EBCAgência Brasil. Retrieved from: https://agenciabrasil.ebc.com.br/economia/noticia/2018-02/uso-decelular-e-acesso-internet-sao-tendencias-crescentes-nobrasilt: : text=Por\%20outro\%20lado\%2C\%20no\%20total, existiam\%20102.633\%20milh\%C3\%B5es $\% 20$ de $\% 20$ televis $\%$ C3\%B5es. Acesso em: 24/11/2020.

Gil, A.C. (2010). Como elaborar projetos de pesquisa? São Paulo. Atlas. 5 ed.

Lévy, P. (2001). O que é virtual. São Paulo: Editora 34.

Mcluhan, M. (2007). Os meios de comunicação como extensão do homem. São Paulo. Cultrix.

Ministério da Saúde. (2020). Protocolo de manejo clínico do coronavírus (COVID-19) na atenção primária à saúde. Secretaria de Atenção Primária a Saúde (SAPS). V. 7. Brasilia.

Ortiz, R. (2006). A moderna tradição brasileira. São Paulo. Brasiliense. 5 ed.

Pena, B.G. (2019). National eMuseum of Sport. In: In DaCosta, L. \& Miragaya, A. - Eds, New Cognitive and Virtual Interactions of Sport Sciences and Studies, Nova Studio, Petrópolis. Retrieved from: http://www.sportsinbrazil.com.br/livros/sport-tech.pdf 